\title{
НОВЫЕ ПОСТУПЛЕНИЯ В КОЛЛЕКЦИЮ МУЗЕЯ ГЕОЛОГИИ И МИНЕРАЛОГИИ ИМ. И.В. БЕЛЬКОВА ГИ КНЦ РАН В 2017 г.
}

\section{Борисова В.В., Волошин А.В., Жихарева Н.Г., Чернявский А.В.}

Геологический институт КНЦРАН, Anamumbl, borisova@geoksc.apatity.ru; vol@geoksc.apatity.ru

Одним из ключевых моментов деятельности музеев является сохранение и приумножение музейных фондов. В последние годы отмечается тенденция активного пополнения музейной коллекции основного и научно-вспомогательного фонда, что свидетельствует об успешном развитии музейного дела в институте.

В 2017 г. основной фонд музея пополнился на 127 образцов, из них 92 образца были выставлены в экспозиции музея. Систематическую коллекцию минералов пополнили 80 образцов, коллекцию с новыми минералами - 10, коллекцию руд - 3 и петрографическую коллекцию - 34 .

Значительно расширилась география поступлений. Наибольшее количество образцов поступило из Хибино - Ловозёрского комплекса - 58. Далее геологические объекты распределились следующим образом: Вороньи тундры - 18, Южное обрамление Печенги - 11, Вуориярви и Ковдор - 7 , Печенгское месторождение - 4, Кейвы, Салла-Куолаярвинская зона и Панареченская структура - по 3 образца, Южное Прихибинье (Пирротиновое ущелье) - 2, Беломорское побережье, массив Падостундра, Мончеплутон и Риж-губа (Мончегорский район) - по одному образцу. В основном фонде музея восстановлены 14 образцов пород Кургинского массива (коллекция И.В. Буссен, А.С. Сахарова, 1976).

Коллекция музея обновилась на 31 минеральный вид: теллур, алексит, бамболлаит, волынскит, вудхаузеит, гафнон, жеффруаит, калаверит, кампелит, кингсмаунтинит, клаусталит, козалит, колорадоит, коннеллит, лепидокрокит, менегинит, монтбрейит, нагиагит, намибит, петцит, радхакришнаит, станнин, теллуровисмутит, тетрадимит, ульманнит, фрейеслебенит, хенриит, цумоит, шмиттерит, эмпрессит и эосфорит (курсивом выделены первые находки в России, подчёркнут новый минеральный вид).

Коллекцию новых минеральных видов Ловозёрского массива дополнили образцы с минералами из пегматитовой залежи «Юбилейная-2», вскрытой подземной выработкой на руднике Карнасурт в начале 2016 г. - баритолампрофиллит (рис. 1), мурманит (по ломоносовиту), пенквилксит, раит и манганонептунит (И.В. Пеков, И.С. Лыкова).

Коллекция Хибинского массива пополнилась образцами с чкаловитом Восточного рудника (г. Коашва), беталомоносовитом и щербаковитом г. Ньорпахк (А.П. Николаев), а также образцом тонковолокнистого лампрофиллита г. Юкспор (И.С. Красоткин).
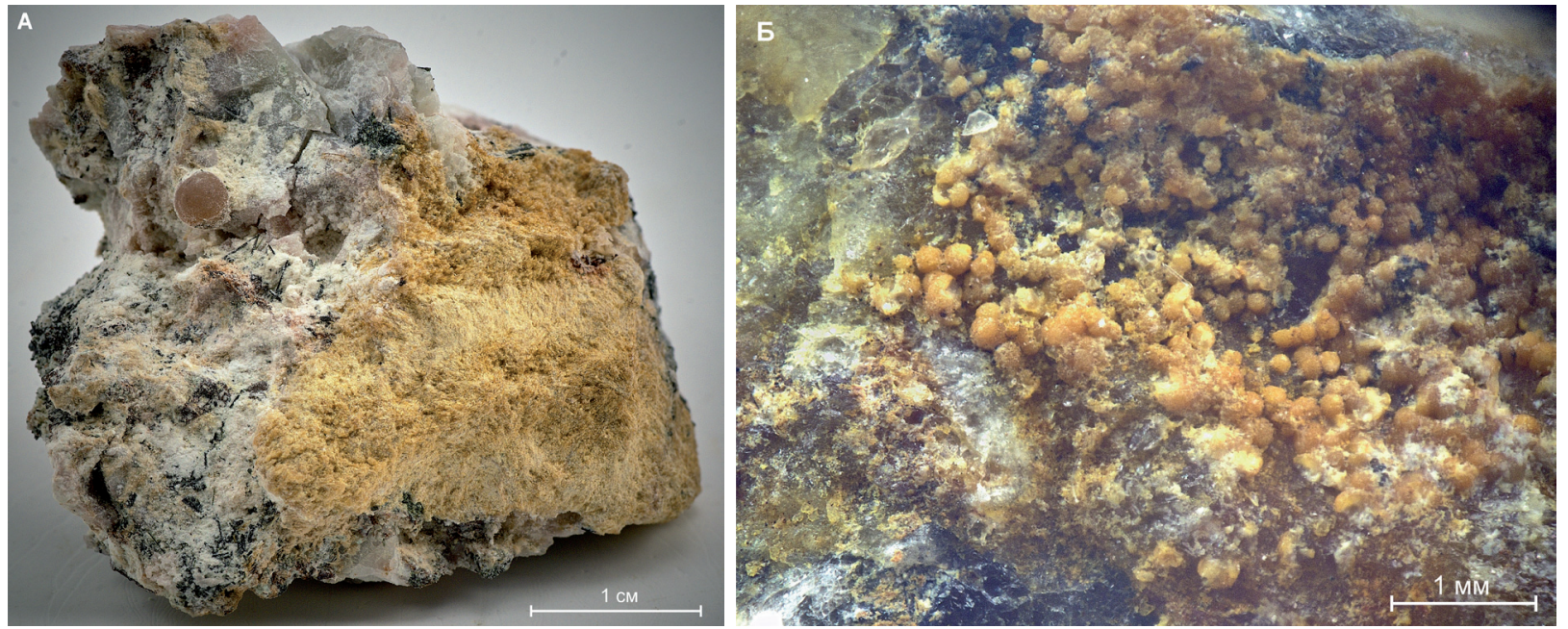

Рис. 1. А - баритолампрофиллит со сферолитом фторапатита. Ловозерский массив, рудник Карнасурт, пегматитовая залежь «Юбилейная-2» (ГИМ 7736); Б - сферолиты эосфорита. Вороньи тундры, г. Васин-Мыльк (ГИМ 7664/1). 
В декабре 2016 г. Международной комиссией по новым минералам (МКННМ ММА) был утверждён новый минеральный вид - кампелит. Это второй скандиевый фосфат, $\mathrm{Ba}_{6} \mathrm{Mg}_{3} \mathrm{Sc}_{8}\left(\mathrm{PO}_{4}\right)_{12}(\mathrm{OH})_{6} \cdot 7 \mathrm{H}_{2} \mathrm{O}$, открытый в Ковдорском массиве после ёнаита [3]. Кампелит был обнаружен в фоскорит-карбонатитовом комплексе на Железном руднике. В открытии участвовал коллектив авторов: В.Н. Яковенчук, Г.Ю. Иванюк, Т.Л. Паникоровский, С.Н. Бритвин, С.В. Кривовичев, В.В. Шиловских и Н.Н. Бочаров. Минерал назван в честь российского горного инженера Ф.Б. Кампеля за его вклад в развитие технологий в рудничном процессе добычи комплексных магнетит-апатит-бадделеитовых руд Ковдорского месторождения. Образец передал в музей В.Н. Яковенчук.

\section{Редкие минеральные виды Кольского региона}

Для уточнения статуса минералов при их паспортизации музеем регулярно проводится диагностика минералов рентгено-фазовым и электронно-зондовым анализом. В 2016-17 гг. в музейных образцах впервые для Кольского региона были установлены намибит - первая находка в России и коннеллит - вторая находка в России. Об этих находках было сделано сообщение на VIII научной сессии, посвящённой Дню российской науки (10 февраля 2017 г.), материалы опубликованы в Трудах XIV Всероссийской Ферсмановской научной сессии [1].

В редкометалльных гранитных пегматитах Вороньих тундр обнаружено около 140 минеральных видов, среди которых 12 новых и большое число редких минералов. Представительную коллекцию образцов с редкими минералами месторождения г. Васин-Мыльк передал А.В. Волошин. Среди них фосфаты - кингсмаунтинит, вудхаузеит, эосфорит (рис. 1) и файрфилдит, сложные оксиды $\mathrm{Ta}$ и $\mathrm{Nb}$ - воджинит и иксиолит, а также первая находка в России и третья в мире - гафнон, $\mathrm{Hf}\left(\mathrm{SiO}_{4}\right)$. Гафнон обнаружен в образцах мелкозернистого грейзена альбит-лепидолит-кварцевого состава из альбитизированных пегматитов. Минерал образует в кристаллах высокогафниевого циркона краевую зону, которая хорошо проявляется на снимках в отражённых электронах и катодной люминесценции. Минерал достоверно диагностируется по химическому составу по преобладанию Hf над $\mathrm{Zr}$ [2].

В колчеданных рудах Южного Прихибинья (Пирротиновое ущелье) в последнее время также обнаружено много редких минералов. Коллекция этого района пополнилась аншлифами с ульманнитом - сульфидом $\mathrm{Ni}$ и $\mathrm{Sb}$ и хенриитом - теллуридом $\mathrm{Cu}$ и $\mathrm{Ag}$ (С.М. Карпов).

В аншлифах из метасоматитов по вулканитам Панареченской структуры представлены редкие минералы, относящиеся как к собственно элементам - теллур, так и к $\mathrm{Au}, \mathrm{Ag}, \mathrm{Bi}, \mathrm{Hg}, \mathrm{Pb}$ теллуридам - волынскит, колорадоит, петцит, теллуровисмутит, цумоит, эмпрессит и радхакришнаит; сульфотеллуридам с $\mathrm{Pb}, \mathrm{Bi}$ - алексит, тетрадимит; $\mathrm{Au}, \mathrm{Pb}$, Те сульфосолям - нагиагит. В ассоциации с ними находятся такие редкие $\mathrm{Ag}, \mathrm{Cu}, \mathrm{Pb}, \mathrm{Fe}$ сульфосоли, как козалит, эмплектит, менегинит, фрейеслебенит, станнин и тетраэдрит (А.В. Чернявский).

Редкими минералами пополнилась коллекция Салла-Куолаярвинской зоны: из метасоматитов участка «Озёрный» в музей поступили аншлифы с такими $\mathrm{Au}, \mathrm{Cu}$ теллуридами, как калаверит и бамболлаит в ассоциации с мелонитом и алтаитом, а также U-Те теллурат - шмиттерит; из кварцевой жилы участка «Кайралы» - аншлиф с теллуридами - монтбрейитом и калаверитом (А.В. Чернявский).

Впервые в коллекции музея появился аншлиф с селенидами $\mathrm{Cu}, \mathrm{Fe}, \mathrm{Ag}$ и $\mathrm{Pb}$ - жеффруаитом и клаусталитом. Сульфиды были обнаружены в плагиопироксенитах Южно-Сопчинского месторождения Мончегорского рудного района (А.В. Чернявский).

В последние годы ведутся активные работы по изучению минералогии колчеданных руд участка Брагино Южного обрамления Печенгской зоны. Часть образцов с редкими минералами из этого участка поступила в музей. Среди них оксиды - лепидокрокит и кульсонит, а также сульфат роценит (А.А. Компанченко). Кульсонит и роценит - вторые находки в Кольском регионе.

Дюмортьерит, боросиликат Al, относится к редким минералам Кольского региона и до сих пор был известен только в редкометалльных пегматитах Вороньих тундр, поэтому находка дюмортьерита в кварцевой жиле, секущей эклогиты участка Куру-Ваара (Ковдорский район) была неожи- 
данной и интересной. А.Н. Конилов передал в музей шлиф с симплектитами высокоглинозёмистых минералов - дюмортьерита, корунда и кианита, с полевым шпатом.

\section{Хибинский щелочной массив}

В феврале 2017 г. в подземном руднике на г. Кукисвумчорр была вскрыта наиболее крупная из известных в пределах щелочных массивов минерализованная полость. В залежи из этой полости, получившей название «Натролитовая», исследователями - И.В. Пековым, А.П. Николаевым и В.Н. Яковенчуком, установлено более 30 минеральных видов. В Выставочном зале музея создана экспозиция минералов этой уникальной залежи. Красочные образцы музейной значимости с друзами кристаллов натролита, пластинчатыми кристаллами кальцита («папиршпата») и «льдистым» натроном (рис. 2), зональными кристаллами микроклина и другими минералами поступили в основной фонд музея от Д.В. Жирова, А.П. Николаева и А.Р. Курбанова.
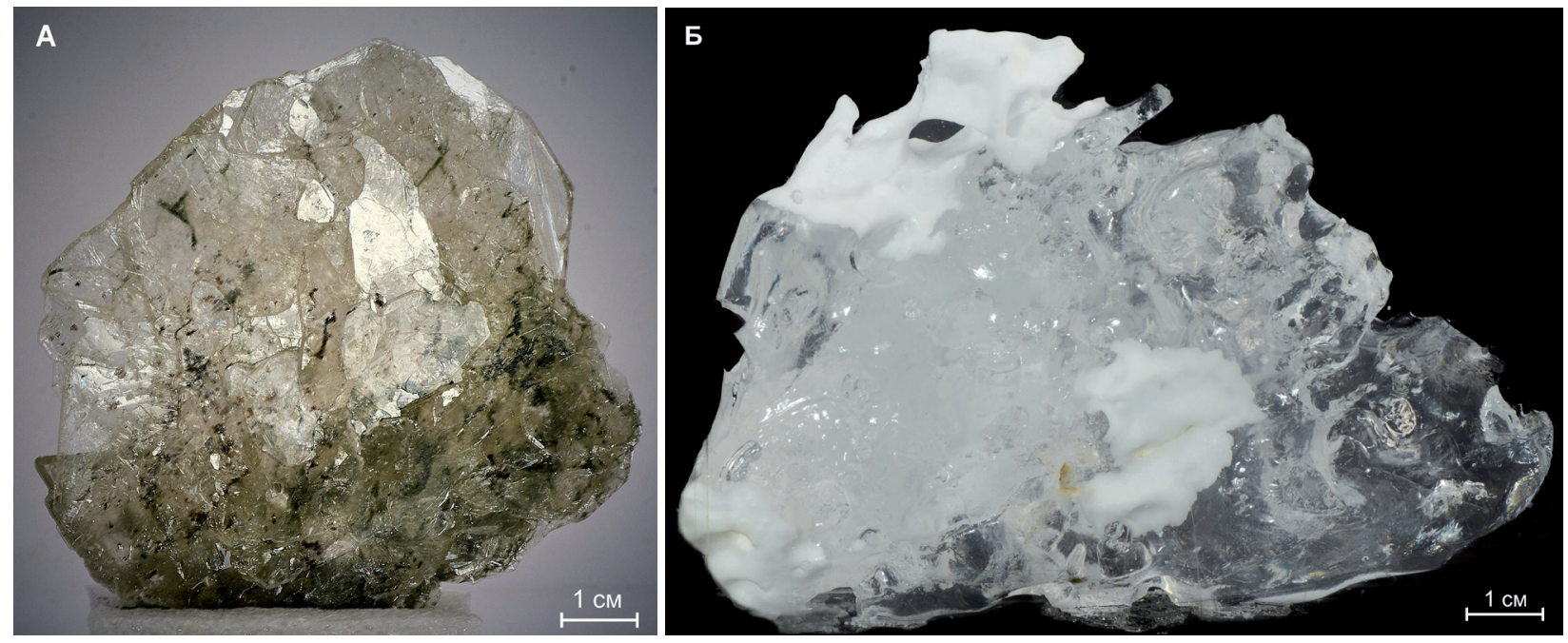

Рис. 2. Кристалл кальцита («папиршпат») - А, натрон - Б. Хибинский массив, Кировский рудник, залежь «Натролитовая» (ГИМ 7672, ГИМ 7694).

Необычные эффектные образцы с ярко-жёлтыми псевдоморфозами по нефелину с г. Вудъяврчорр переданы И.С. Красоткиным и Г.С. Ильиным. В составе псевдоморфоз рентгено-фазовым анализом определена смесь минералов из шабазита, анальцима и кальцита.

Коллекция Хибинского массива пополнилась образцом керна скважины с анкилитом и сульфидами в карбонатите из карбонатитового штока района р. Тульйок (Е.Н. Козлов), а также образцами из старых коллекций института - микроклином с хорошо выраженными зонами роста, дельхайелитом (г. Кукисвумчорр, отвалы Кировского рудника) и альстонитом (г. Ньорпахк).

\section{Ловозёрский массив}

К наиболее красочным образцам нового поступления относятся образцы с виллиомитом, радиально-лучистыми агрегатами эгирина (рис. 3), сферолитами фторапатита и коричнево-красным эвдиалитом с г. Карнасурт, а также образцы с кристаллами циркона с Умбозерского рудника (В.А. Нивин, В.В. Пуха). Кроме того, экспозиция массива пополнилась крупными, до 6-7 см в длину, кристаллами фторапатита с г. Леппхе (коллекция А.Н. Кулакова) и оригинальными образцами с кавернозным натролитом и волокнистым травяно-зелёным эгирином в розовом натролите из пегматитовой залежи «Юбилейная», г. Карнасурт (коллекция И.В. Буссен).

\section{Другие геологические объекты Кольского регчона}

Экспозицию массива Вуориярви обновили 3 образца из старых коллекций института - с фторапатитом, флогопитом, магнетитом, канкринитом и актинолитом (коллекция Л.В. Козыревой). 

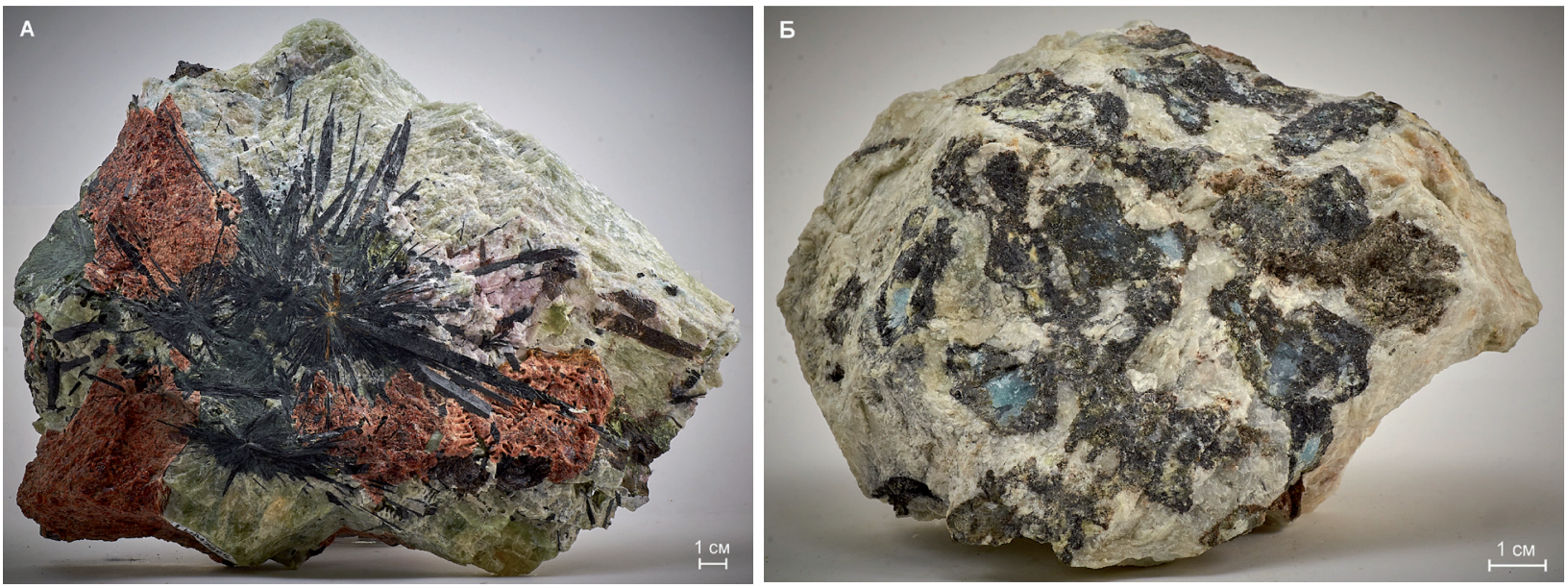

Рис. 3. А - радиально-лучистые агрегаты эгирина в пегматите. Ловозёрский массив, г. Карнасурт (ГИМ 7665); Б - кальцитовый карбонатит с гнёздами ковдорскита. Ковдорский массив, Железорудное месторождение (ГИМ 7678).

Коллекция минералов Западных Кейв пополнилась образцом с экандрюситом из пегматитов в щелочных гранитах Белых тундр (А.В. Волошин) и образцом с таблитчатыми кристаллами апатита из силекситов района г. Чанейшпахк (коллекция И.В. Белькова).

Коллекцию минералов редкометалльных пегматитов Вороньих тундр, г. Васин-Мыльк, дополнили красочные образцы с кристаллами серебристо-сиреневого лепидолита (А.В. Волошин).

В коллекции руд впервые появился образец с хромит-магнетитовыми рудами гипербазитового массива Падос, южное обрамление Лапландского гранулитового пояса (П.А. Серов). Коллекцию дополнили образцы сплошных сульфидных медно-никелевых руд Печенги, месторождение «Заполярное» (Ю.Н. Нерадовский) и магнетитовых руд Железорудного месторождения Ковдорского массива (Д.В. Жиров).

В последние годы интенсивно расширяется экспозиция Петрографического отдела музея. В 2017 г. из 34 поступивших образцов различных пород 20 были выставлены в экспозиции. Среди них - эффектный образец кальцитового карбонатита с гнёздами ковдорскита (рис. 3) Железорудного месторождения Ковдорского массива (А.А. Завьялов).

Экспозицию пород Печенгской рифтогенной структуры украсил оригинальный образец с магнетит-тальк-диопсидовым обособлением в серпентиновой жиле массива Пильгуярви (Ю.Н. Нерадовский), а также образцы с кальцит-серпентиновыми прожилками в метаультрабазитах месторождения «Заполярное» (Ю.Л. Войтеховский).

Большую коллекцию из красивейших полированных штуфов тингуаитов Хибинского массива (гор Тахтарвумчорр, Кукисвумчорр и Поачвумчорр) передал В.Л. Семёнов. Это позволило вместе с другими образцами тингуаитов, имевшихся в коллекции музея, оформить постоянную экспозицию «Тингуаиты Хибин» в Выставочном зале музея.

Впервые в петрографической коллекции музея появился образец, представляющий собой реликт древнейшей коры выветривания гранитоидного фундамента, Риж-губа Мончегорский район (В.И. Пожиленко, Д.В. Жиров).

\section{Источники поступлений}

В пополнении коллекции музея принимали участие следующие сотрудники Геологического института: Ю.Л. Войтеховский, А.В. Волошин, В.А. Нивин, В.Н. Яковенчук, Ю.Н. Нерадовский, В.И. Пожиленко, С.М. Карпов, П.А. Серов, Е.Н. Козлов, Д.В. Жиров, А.В. Чернявский, А.А. Компанченко, В.В. Пуха, В.Л. Семёнов. В дар получены образцы минералов и пород от сотрудников других организаций и коллекционеров-любителей - И.В. Пекова (МГУ, г. Москва), И.С. Лыковой (музей им. А.Е. Ферсмана, г. Москва), А.Н. Конилова (ГИН, г. Москва), И.С. Красоткина (ПетрГУ, г. Кировск), А.П. Николаева (г. Кировск), Г.С. Ильина (ИИЕТ им. С.И. Вавилова, г. Москва), 
А.Л. Лескова (г. Кировск), В.И. Петровой (г. Кировск), А.Р. Курбанова (АО «Апатит») и А.А. Завьялова (Ковдорский ГОК).

Музей глубоко признателен всем, кто содействовал пополнению музейных фондов и надеется на дальнейшее плодотворное сотрудничество. Фотографии образцов выполнены младшим научным сотрудником ГИ КНЦ РАН А.В. Чернявским.

\section{Литература}

1. Волошин А.В., Компанченко А.А., Карпов С.М., Борисова В.В. Новые данные о минералах. Вып. 3. Первые находки в России и в Кольском регионе // Труды Ферсмановской научной сессии ГИ КНЦ РАН. Апатиты: Изд-во КНЦ РАН. 2017. С. 71-77.

2. Кудряшов Н.М., Волошин А.В., Удоратина О.В. Высокогафниевый циркон из редкометалльных пегматитов месторождения Васин-Мыльк (Кольский регион) // Труды Ферсмановской научной сессии ГИ КНЦ РАН. Апатиты: Изд-во КНЦ РАН. 2017. С. 120-125.

3. Лиферович Р.П., Яковенчук В.Н., Пахомовский Ю.А. Ёнаит, $\mathrm{CaMgSc}\left(\mathrm{PO}_{4}\right)_{2}(\mathrm{OH}) \cdot 4 \mathrm{H}_{2} \mathrm{O}$ - новый минерал скандия из доломитовых карбонатитов Ковдорского массива // ЗВМО. 1997. Т. 126. № 4. С. 80-88. 